\section{Fumigation of Fruit with Acetic Acid to Prevent Postharvest Decay}

\author{
P.L. Sholberg and A.P. Gaunce \\ Agriculture and Agri-Food Canada, Research Centre, Summerland, British \\ Columbia, VOH 1Z0, Canada
}

Additional index words. Botrytis cinerea, Penicillium expansum, apple, vapor, volatiles

\begin{abstract}
Acetic acid (AA) as a vapor at low concentrations was effective in preventing fruit decay by postharvest fungi. Fumigation with 2.7 or $5.4 \mathrm{mg} \mathrm{AA} / \mathrm{liter}$ in air at 2 and 20C reduced germination of Botrytis cinerea Pers. and Penicillium expansum Link conidia to zero after they had been dried on 0.5-cm square pieces of dialysis tubing. Decay of 'Golden Delicious', 'Red Delicious', and 'Spartan' apples (Malus domestica Borkh.) inoculated with $20 \mu \mathrm{I}$ drops of conidia of $B$. cinerea $\left(1.0 \times 10^{5}\right.$ conidia/ml $)$ or $P$. expansum $\left(1.0 \times 10^{6}\right.$ conidia/ml) was prevented by fumigating with 2.0 and $2.7 \mathrm{mg} \mathrm{AA} / \mathrm{liter}$, respectively. Tomatoes (Lycopersicon esculentum Mill.), grapes (Vitis vinifera L.), and kiwifruit [Actinidia deliciosa (A. Chev.) C.F. Liang et R. Ferguson var. deliciosa] inoculated with B. cinerea or navel oranges (Citrus sinensis L.) inoculated with $P$. italicum Wehmer did not decay when fumigated with $2.0 \mathrm{mg} \mathrm{AA} /$ liter at 5C. AA fumigation at low temperatures (1 and 5C) with $2.0 \mathrm{or} 4.0 \mathrm{mg}$ AA/liter prevented decay of 'Spartan' and 'Red Delicious' apples and 'Anjou' pears (Pyrus communis L.) inoculated with $B$. cinerea and $P$. expansum, respectively. 'Spartan' apples immersed in a suspension of $P$. expansum conidia $\left(1.4 \times 10^{5}\right.$ conidia $\left./ \mathrm{ml}\right)$ and fumigated with $2.7 \mathrm{mg} \mathrm{AA} /$ liter at $5 \mathrm{C}$ had an average of 0.7 lesions per fruit compared to 6.1 for nontreated fruit. Increasing the relative humidity from $17 \%$ to $98 \%$ increased the effectiveness of AA fumigation at 5 and $20 \mathrm{C}$. At the concentrations used in our trials, AA had no apparent phytotoxic effects on the fruit. The potential for commercial fumigation with AA to control postharvest decay of fruit and vegetables appears promising.
\end{abstract}

To our knowledge, accurate data are not available on the magnitude of economic losses resulting from diseases affecting susceptible fruit, vegetable, and root crops during storage and in transit to market. However, worldwide losses in the postharvest period range from $10 \%$ to $50 \%$, particularly in developing countries that lack sophisticated postharvest storage facilities (Jeffries and Jeger, 1990). Based on relatively conservative estimates, the amount of food lost annually could feed between 200 and 300 million people per year (Kelman, 1989). For these reasons, it is essential that losses due to postharvest decay are reduced to the lowest possible levels. Fungicides are useful but can leave residues and have been associated with potential oncogenic risks (Wilson and Wisniewski, 1989; Wilson et al., 1991). Biological controls have been developed (Janisiewicz, 1988, 1991), and recently, two natural microbial agents were granted registration in the United States. However, their commercial success remains to be demonstrated.

Acetic acid (AA) is a universal metabolic intermediary and occurs in plants and animals. It is present at $\geq 4 \%$ in vinegar (Busta and

Received for publication $15 \mathrm{Feb}$. 1995. Accepted for publication 18 June 1995. Sumerland Research Centre Contribution no. 836. We thank Paula Haag for technical assistance. The cost of publishing this paper was defrayed in part by the payment of page charges. Under postal regulations, this paper therefore must be hereby marked advertisement solely to indicate this fact. the and undissociated AA can penetrate the microbial cell to exert its toxic effect
(Banwart, 1981). Our goal was to determine if AA as a vapor is toxic to fungal conidia and if it could be used to prevent postharvest decay of fruit, especially decay of apples caused by Botrytis cinerea and Penicillium expansum.

\section{Materials and Methods}

Fumigation procedure. Four 12.7-liter fumigation chambers were constructed in our laboratory from 11-kg-capacity tin cans for solid material (Fisher Scientific, Ottawa, Canada). A chamber circulation fan was devised by modifying a 0.6 -amp, 115 -V, beverage circulation pump (Little Giant Pump Co., Oklahoma City, Okla.). The pump shaft casing was removed, and the motor cooling and pump impellers were exchanged. The motor was attached to the top of the chamber lid with the shaft entering the chamber through a Swagelock (Columbia Valve and Fitting, North Vancouver, B.C., Canada) bulkhead fitting with a teflon ferule to provide an airtight fit. The lid was provided with a rubber septum for AA application and a microscope slide viewing port. A strip of filter paper was attached to the bottom of the lid underneath the septum and viewing port. When we conducted a fumigation, the lids were removed and samples were placed in the chamber. The lid was tightly applied and sealed with duct tape. The circulation fan was turned on and reagent-grade glacial AA was injected via a microsyringe into the chamber through the septum onto the filter paper wick. The AA completely evaporated in 1 to 4 min depending on the volume applied and the temperature. Air circulation was maintained for $30 \mathrm{~min}$ to evaporate the AA and

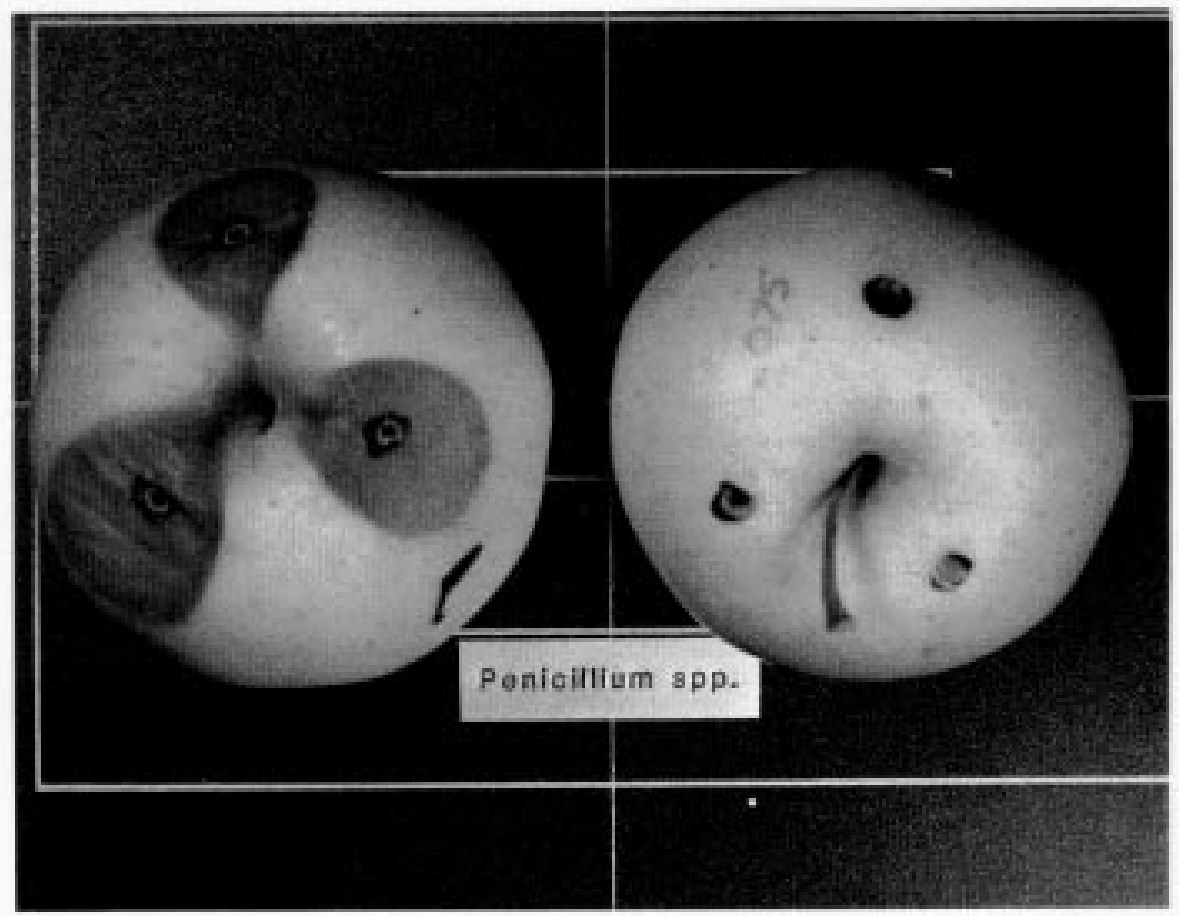

Fig. 1. Effect of acetic acid fumigation in preventing decay on fruit inoculated with Penicillium expansum. 'Golden Delicious' apples were inoculated with drops $(20 \mu \mathrm{l})$ of $P$. expansum conidia in a water suspension containing $1.0 \times 10^{6}$ conidia/ml. The conidia were placed in three circles on each fruit inscribed with a black marking pen, allowed to dry, treated, and injured with a glass rod $(3 \mathrm{~mm}$ in diameter). The apple on the right was fumigated with acetic acid at $2.0 \mathrm{mg} \cdot 1 \mathrm{iter}-1$ for $60 \mathrm{~min}$ at $5 \mathrm{C}$. 

most of the experiments, the chamber remained closed for $60 \mathrm{~min}$, when the top was removed and the samples were placed in a laminar flow hood for aeration for $\approx 30 \mathrm{~min}$. Fumigations were done in temperature- and humidity-controlled rooms (Conviron Products Co., Winnipeg, Man., Canada) with preconditioning of the samples to the experimental temperature and humidity. ing some fumigations was monitored with a photoionization detector (Photovac model 10530; Markham, Ont., Canada) connected to an integrator (HP 3390a; Hewlett Packard Co., San Francisco).

Cultures. Botrytis cinerea and Penicillium expansum cultures, originally isolated from infected apples, were grown at $22 \pm 2 \mathrm{C}$ for 7 to 14 days on potato dextrose agar (PDA). Water suspensions of conidia from these cultures were prepared by scraping conidia from the culture surface with a sterile loop and placing them in test tubes containing $10 \mathrm{ml}$ of sterile water. Conidia concentrations for each test was determined with a hemacytometer (American Optical Corp., Buffalo, N.Y.).

Fumigation of conidia on PDA. Drops (20 $\mu \mathrm{l})$ containing $B$. cinerea $\left(1.0 \times 10^{5} / \mathrm{ml}\right)$ and $P$. expansum $\left(1.0 \times 10^{6} / \mathrm{ml}\right)$ conidia were placed on PDA at six equidistant points on plastic petri plates ( $9 \mathrm{~cm}$ in diameter) containing 15 $\mathrm{ml}$ of medium. One plate each of $B$. cinerea and $P$. expansum per fumigation chamber were uncovered and fumigated at dosages of 5.9 to $13.4 \mathrm{mg} \mathrm{liter}^{-1}$ at 2 and $22 \mathrm{C}$. The plates were removed from the chambers after $120 \mathrm{~min}$, the covers were replaced, and the plates were incubated at $22 \pm 2 \mathrm{C}$ for $24 \mathrm{~h}$. Percent germination of conidia was determined by counting 100 conidia in each drop under $\times 160$ or $\times 400$ magnification with a compound microscope.

Fumigation of conidia on dialysis tubing. Fumigation of conidia on dialysis tubing was conducted to determine if conidia on dry surfaces could be killed by AA. Drops $(20 \mu \mathrm{l})$ of B. cinerea $\left(1.0 \times 10^{5} / \mathrm{ml}\right)$ and $P$. expansum $(1.0$ $\times 10^{6} / \mathrm{ml}$ ) conidia on $0.5-\mathrm{cm}$ square pieces of dialysis tubing (cellulose dialysis tubing; Sargent-Welch Scientific of Canada, Calgary, Canada) were dried in a laminar flow hood for $\geq 1 \mathrm{~h}$. Once dry the squares were conditioned to $95 \%$ relative humidity ( $\mathrm{RH}$ ) for $1 \mathrm{~h}$ and then fumigated with 0 to $16.0 \mathrm{mg}$ AA/liter for $\geq 20$ min or $4.0 \mathrm{mg} \mathrm{AA} / \mathrm{liter}$ for $10,20,40$, or 80 $\mathrm{min}$. The fumigations were performed in a 20 $\pm 0.1 \mathrm{C}$ room maintained at $95 \% \pm 5 \% \mathrm{RH}$. Percent germination of conidia or number of circulate the vapor within the chamber. In

The AA concentration in the chamber dur-

colonies was evaluated after the squares were placed on PDA buffered with $0.2 \mathrm{M}$ phosphate buffer (pH 6.9) and incubated at 22C for $24 \mathrm{~h}$.

Fumigation of conidia on fruit applied in drops. Apples from cold storage (1C) were allowed to warm to $22 \pm 2 \mathrm{C}$ over $24 \mathrm{~h}$. After the surface of each apple was wiped with $95 \%$ ethanol in a laminar flow hood, three circles $(0.5 \mathrm{~cm}$ in diameter) were inscribed equidistant from one another near the apple stem with a marking pen (Fig. 1). Drops $(20 \mu \mathrm{l})$ of conidia were placed within each circle and allowed to dry for $\geq 1 \mathrm{~h}$. Six apples, consisting of three inoculated with $P$. expansum $(1.0 \times$ $10^{6}$ conidia $/ \mathrm{ml}$ ) and three inoculated with $B$. cinerea $\left(1.0 \times 10^{5}\right.$ conidia $\left./ \mathrm{ml}\right)$, were placed in a fumigation chamber. The fruit were fumigated for $60 \mathrm{~min}$ in a $5 \pm 0.1 \mathrm{C}$ or $20 \pm 0.1 \mathrm{C}$ room maintained at $95 \%$ to $100 \% \mathrm{RH}$. The same procedure was repeated for each concentration of AA tested. After fumigation, the fruit was aerated in a laminar flow hood for 30 min. A glass rod (3 $\mathrm{mm}$ in diameter) with a protruding sharp point was used to injure the fruit in each inscribed circle by puncturing to a depth of $\approx 0.5 \mathrm{~cm}$. The glass rod was dipped in $95 \%$ ethanol and flamed after each treatment. Fruit incubated at $22 \pm 2 \mathrm{C}$ in plastic containers designed for fruit storage were examined for decay after 6 days, when the diameter of each lesion was measured and recorded. Three cultivars of apple and 'Anjou' pear were fumigated following the previously described procedure, as were navel oranges inoculated with $P$. italicum $\left(3.0 \times 10^{6} / \mathrm{ml}\right)$ conidia and seedless grapes, kiwifruit, and tomatoes inoculated with $B$. cinerea $\left(1.0 \times 10^{5}\right.$ conidia/ml).

The effect of 2.0 and $2.7 \mathrm{mg}$ AA/liter vapor on $1.0 \times 10^{2}$ to $10^{5} P$. expansum conidia $/ \mathrm{ml}$ was studied on 'McIntosh' apples. Fruit were inoculated with drops $(20 \mu \mathrm{l})$, fumigated for $60 \mathrm{~min}$ at $5 \pm 0.1 \mathrm{C}$, injured, and incubated for 7 days at $22 \pm 2 \mathrm{C}$, when the diameter of each lesion was measured and recorded.

The effect of low temperature on AA fumigation was studied at $1 \pm 0.1$ and $5 \pm 0.1 \mathrm{C}$ on 'Red Delicious' and 'Spartan' apples. Fumigation chambers and fruit inoculated with 20 $\mu 1$ drops of $P$. expansum $\left(7.8 \times 10^{9} / \mathrm{ml}\right)$ or $B$. cinerea $\left(4.4 \times 10^{4} / \mathrm{ml}\right)$ conidia were placed in a 1 or $5 \mathrm{C}$ room maintained at a constant $95 \%$ to $100 \% \mathrm{RH}$ for $12 \mathrm{~h}$. The fruit was fumigated for 60 min with $\mathrm{AA}$ concentrations ranging from 2.0 to $5.4 \mathrm{mg} \cdot$ liter $^{-1}$. After fumigation, fruit were aerated, injured, and incubated at 22 $\pm 2 \mathrm{C}$ for 7 days, when the diameters of the lesions were measured and recorded.

Table 1. Percent germination of Botrytis cinerea and Penicillium expansum conidia on potato dextrose agar fumigated with acetic acid at 2 and $22 \mathrm{C}$.

\begin{tabular}{|c|c|c|c|c|}
\hline \multirow{3}{*}{$\begin{array}{l}\text { Acetic } \\
\text { acid } \\
\left(\mathrm{mg} \cdot \text { liter }^{-1}\right)\end{array}$} & \multicolumn{4}{|c|}{ Germination (\%) } \\
\hline & \multicolumn{2}{|c|}{ B. cinerea } & \multicolumn{2}{|c|}{ P. expansum } \\
\hline & $2 \mathrm{C}$ & $22 \mathrm{C}$ & $2 \mathrm{C}$ & $22 \mathrm{C}$ \\
\hline 0 & $100 \pm 0^{2}$ & $100 \pm 0$ & $100 \pm 0$ & $100 \pm 0$ \\
\hline 5.4 & $13.9 \pm 24.4$ & $10.3 \pm 23.3$ & $---^{y}$ & --- \\
\hline 8.0 & $0.0 \pm 0.0$ & $0.0 \pm 0.0$ & $0.8 \pm 1.4$ & $0.0 \pm 0.0$ \\
\hline 10.8 & $0.0 \pm 0.0$ & $0.0 \pm 0.0$ & $0.0 \pm 0.0$ & $0.0 \pm 0.0$ \\
\hline 13.4 & --- & --- & $0.0 \pm 0.0$ & $0.0 \pm 0.0$ \\
\hline
\end{tabular}

${ }^{2}$ Percentage $\pm \mathrm{SD}$

${ }^{\mathrm{y}}$ Not tested.
The effect of RH on AA fumigation was studied. 'Spartan' apples inoculated with 20$\mu$ drops of $P$. expansum $\left(1.0 \times 10^{6} / \mathrm{ml}\right)$ or $B$. cinerea $\left(1.2 \times 10^{4} / \mathrm{ml}\right)$ conidia were placed in two $5 \pm 0.1 \mathrm{C}$ rooms set at $17 \% \pm 2 \%$ and $98 \%$ $\pm 2 \% \mathrm{RH}$ for $24 \mathrm{~h}$ before they were fumigated with 2.0 and $2.7 \mathrm{mg} \mathrm{AA} /$ liter. At these $\mathrm{RH}$ values, the vapor pressure deficit (VPD) was 0.72 and $0.02 \mathrm{kPa}$, respectively. The experiment was repeated at $20 \pm 0.1 \mathrm{C}$ in the same rooms at the same RHs (VPD of 1.94 and 0.47 $\mathrm{kPa}$, respectively) with $P$. expansum $\left(4.0 \times 10^{5}\right.$

Table 2. Percent germination of Botrytis cinerea and Penicillium expansum conidia on dialysis tubing fumigated with acetic acid at $95 \%$ relative humidity and $20 \mathrm{C}$.

\begin{tabular}{lcc}
\hline \multirow{2}{*}{$\begin{array}{l}\text { Acetic acid } \\
\left(\mathrm{mg} \text { liter }^{-1}\right)\end{array}$} & \multicolumn{2}{c}{ Germination $(\%)$} \\
\cline { 2 - 3 } 0.0 & B. cinerea & P. expansum \\
2.7 & $0.0 \pm 0.0$ & $100 \pm 0$ \\
4.0 & $--0^{\mathrm{y}}$ & $---^{\mathrm{y}}$ \\
5.4 & $0.0 \pm 0.0$ & $--^{\mathrm{x}}$ \\
8.0 & $1.7 \pm 2.3$ & $0.0 \pm 0.0$ \\
10.8 & $0.0 \pm 0.0$ & $0.0 \pm 0.0$ \\
\hline
\end{tabular}

${ }^{2}$ Percentage \pm SD.

yot tested.

${ }^{\mathrm{x}}$ Germination occurred at this concentration, but the percentage was not recorded.

Table 3. Number of Botrytis cinerea and Penicillium expansum colonies that grew on dialysis tubing squares after fumigation with acetic acid at $4.0 \mathrm{mg} \cdot \mathrm{liter}^{-1}$ for 10 to $80 \mathrm{~min}$ at $20 \mathrm{C}$.

\begin{tabular}{lcc}
\hline \hline \multirow{2}{*}{ Time } & \multicolumn{2}{c}{ Colonies/no. square } \\
\cline { 2 - 3 } (min) & B. cinerea $^{z}$ & P. expansum \\
\hline 0 (control) & $3 / 3$ & $3 / 3$ \\
10 & $0 / 6$ & $4 / 6$ \\
20 & $0 / 6$ & $0 / 6$ \\
40 & $0 / 6$ & $0 / 6$ \\
80 & $0 / 6$ & $0 / 6$ \\
\hline
\end{tabular}

${ }^{\mathrm{z}}$ Dialysis tubing squares were each inoculated with a $20-\mu 1$ drop containing $1.0 \times 10^{5} \mathrm{~B}$. cinerea conidia/ $\mathrm{ml}$.

yialysis tubing squares were each inoculated with a $20-\mu \mathrm{l}$ drop containing $1.0 \times 10^{6} \mathrm{P}$. expansum conidia/ml.

Table 4. Average lesion diameter on fruit inoculated with $20-\mu 1$ drops of Botrytis cinerea $\left(1.0 \times 10^{5}\right.$ conidia/ml) and fumigated with acetic acid for 1 $\mathrm{h}$ at $5 \mathrm{C}$.

\begin{tabular}{|c|c|c|}
\hline \multirow[b]{3}{*}{ Cultivar } & \multicolumn{2}{|c|}{ Lesion diam (mm) } \\
\hline & \multicolumn{2}{|c|}{ Acetic acid $\left(\mathrm{mg} \cdot\right.$ liter $\left.^{-1}\right)$} \\
\hline & 0.0 & $2.0^{z}$ \\
\hline \multicolumn{3}{|l|}{ Apples } \\
\hline \multicolumn{3}{|l|}{ Golden } \\
\hline Delicious & $43.6 \pm 3.8^{y}$ & $0.0 \pm 0.0$ \\
\hline Red Delicious & $28.2 \pm 4.6$ & $0.0 \pm 0.0$ \\
\hline Spartan & $2.4 \pm 4.2$ & $0.0 \pm 0.0$ \\
\hline \multicolumn{3}{|l|}{ Grapes } \\
\hline \multicolumn{3}{|l|}{ Thompson } \\
\hline Seedless & $10.0 \pm 0.0$ & $0.0 \pm 0.0$ \\
\hline \multicolumn{3}{|l|}{ Kiwifruit } \\
\hline Hayward & $10.0 \pm 0.0$ & $0.0 \pm 0.0$ \\
\hline \multicolumn{3}{|l|}{ Pears } \\
\hline Anjou & $43.2 \pm 12.3$ & $0.0 \pm 0.0$ \\
\hline Tomato fruit ${ }^{\mathrm{x}}$ & $33.2 \pm 10.0$ & $0.0 \pm 0.0$ \\
\hline
\end{tabular}

HortScience, Vol. 30(6), October 1995 
conidia $/ \mathrm{ml})$ and $B$. cinerea $\left(1.2 \times 10^{4}\right.$ conidia/ $\mathrm{ml})$. RH was monitored with a RH meter (model BA-3313-00; Cole Palmer, Chicago) before and after fumigation.

Fumigation of fruit immersed in a conidial suspension. 'Spartan' apples from cold storage (1C) were allowed to equilibrate to $22 \pm 2 \mathrm{C}$ for $24 \mathrm{~h}$. The apples were inoculated by dipping each fruit in a water suspension of $P$. expansum conidia $\left(1.4 \times 10^{5} / \mathrm{ml}\right)$ for $30 \mathrm{sec}$. After the apples had dried in a laminar flow hood for $2 \mathrm{~h}, 20$ apples were placed in each fumigation chamber, which filled the chamber up to the fan impeller. Four AA concentrations, ranging from 2.0 to $5.4 \mathrm{mg} \cdot \mathrm{liter}^{-1}$, were applied simultaneously for $60 \mathrm{~min}$ at $5 \pm 0.1 \mathrm{C}$. The control fruit were kept in the same room. Immediately after treatment, the fruit were removed from the chambers and placed in a laminar flow hood in a $22 \pm 2 \mathrm{C}$ room, where they were aerated for $\geq 30 \mathrm{~min}$ and injured with a glass rod ( $3 \mathrm{~mm}$ in diameter) at 12 locations from top to bottom over the fruit surface. The fruit were incubated at $22 \pm 2 \mathrm{C}$ for 7 days, when the number of lesions on each fruit was recorded.

\section{Results}

Fumigation of conidia on PDA. Fumigation of $B$. cinerea conidia with $5.4 \mathrm{mg} \mathrm{AA} /$ liter at 2 or $22 \mathrm{C}$ effectively reduced germination from $100 \%$ to $<14 \%$ (Table 1). Conidia of $B$. cinerea and $P$. expansum did not germinate after treatment with $8.0 \mathrm{mg} \mathrm{AA} / \mathrm{liter}$ at $22 \mathrm{C}$ or $10.8 \mathrm{mg} \mathrm{AA} /$ liter at $2 \mathrm{C}$.

Fumigation of conidia on dialysis tubing. Germination of $B$. cinerea and $P$. expansum conidia was reduced from $100 \%$ to $0 \%$ with 2.7 and $5.4 \mathrm{mg} \mathrm{AA} /$ liter, respectively (Table 2). Botrytis cinerea and $P$. expansum colonies did not form after fumigation with $4.0 \mathrm{mg} \mathrm{AA} /$ liter for 10 and $20 \mathrm{~min}$, respectively, on buffered PDA (Table 3 ).

Fumigation of conidia on fruit applied in drops. Three apple cultivars, seedless grapes, kiwifruit, tomatoes, and 'Anjou' pears, which were inoculated with conidia of $B$. cinere $a$ and fumigated with 2.0 to $5.7 \mathrm{mg} \mathrm{AA} /$ liter at $5 \mathrm{C}$, did not decay after being injured and incubated for 7 days at $22 \pm 2 \mathrm{C}$ (Table 4). Apples and 'Anjou' pears inoculated with conidia of $P$. expansum required higher AA doses to prevent decay, but navel oranges, inoculated with $P$. italicum did not (Fig. 1, Table 5). These fumigation rates did not cause any discoloration or apparent phytotoxicity of the fruit used in these trials.

Effectiveness of AA fumigation was studied on 'McIntosh' apples inoculated with $10^{2}$ to $10^{5}$ P. expansum conidia/ml (Table 6). AA vapor at $2.0 \mathrm{mg}$ liter ${ }^{-1}$ was effective when the inoculum concentration was $1 \times 10^{2}$ conidia/ $\mathrm{ml}$, which reduced the mean lesion diameter from 16 to $<2 \mathrm{~mm}$, but was much less effective when $1 \times 10^{4}$ conidia/ml was applied, which reduced the mean diameter by only $9 \mathrm{~mm}$. AA at $2.7 \mathrm{mg} \cdot 1$ iter $^{-1}$ completely prevented decay at all tested concentrations of fungal spores.

The effectiveness of AA was compared at 1 and $5 \mathrm{C}$ on 'Red Delicious' and 'Spartan' apples (Table 7). Conidia of B. cinerea did not cause decay on either apple cultivar at 1 or $5 \mathrm{C}$ at a concentration as low as $2.0 \mathrm{mg}$ AA/liter. Fumigation of 'Red Delicious' apples inoculated with $P$. expansum conidia was more effective at $1 \mathrm{C}$, with $2.0 \mathrm{mg}$ AA/liter reducing mean lesion diameter to $<2 \mathrm{~mm}$ compared to $29 \mathrm{~mm}$ at 5C. However, on 'Spartan', the reverse was true, and $\mathrm{AA}$ fumigation at $5 \mathrm{C}$ was more effective, reducing mean lesion di- ameter to $25 \%$ of the control compared to no reduction at $1 \mathrm{C}$. Decay caused by $P$. expansum was reduced to zero on both cultivars by 2.7 mg AA/liter at $1 \mathrm{C}$ and $4.0 \mathrm{mg}$ AA/liter at 5C.

The effect of RH on AA fumigation was studied at 5 and 20C (Table 8). Fumigation of B. cinerea conidia with 2.0 or $2.7 \mathrm{mg}$ AA/liter was ineffective at $17 \% \mathrm{RH}$ but effective at 98\% RH. Generally, lesion diameter was smaller at $20 \mathrm{C}$ than at $5 \mathrm{C}$. Tests with $P$.

Table 5. Average lesion diameter on fruit inoculated with $20-\mu 1$ drops of Penicillium expansum $\left(1.0 \times 10^{6}\right.$ conidia/ml) and fumigated with acetic acid for $1 \mathrm{~h}$ at $5 \mathrm{C}$.

\begin{tabular}{lcccr}
\hline & \multicolumn{4}{c}{ Lesion diam $(\mathrm{mm})^{\mathrm{z}}$} \\
\cline { 2 - 4 } & \multicolumn{4}{c}{ Acetic acid $\left(\mathrm{mg} \cdot \mathrm{liter}^{-1}\right)$} \\
\cline { 2 - 4 } Cultivar & 0.0 & 2.0 & 2.7 & $4.0^{\mathrm{z}}$ \\
\hline Apples & $38.8 \pm 2.3^{\mathrm{y}}$ & $12.9 \pm 12.5$ & $0.0 \pm 0.0$ & $0.0 \pm 0.0$ \\
$\quad$ Golden Delicious & $34.3 \pm 3.0$ & $29.2 \pm 5.2$ & $6.5 \pm 6.4$ & $0.0 \pm 0.0$ \\
$\quad$ Red Delicious & $30.7 \pm 2.0$ & $8.0 \pm 3.8$ & $3.0 \pm 5.2$ & $0.0 \pm 0.0$ \\
$\quad$ Spartan & $50.0 \pm 0.0$ & $0.0 \pm 0.0$ & $0.0 \pm 0.0$ & $0.0 \pm 0.0$ \\
Oranges & & & & $0.0 \pm 0.0$ \\
$\quad$ Navel & $30.5 \pm 4.8$ & $16.1 \pm 11.0$ & $12.1 \pm 6.9$ & 0.0 \\
Pears & Anjou & &
\end{tabular}

${ }^{2}$ Lesions also did not form following exposure to acetic acid at $5.7 \mathrm{mg} \cdot \mathrm{liter}^{-1}$.

yPercentage \pm SD.

${ }^{x}$ Navel oranges from California were inoculated with $20-\mu l$ drops of $P$. italicum $\left(3.0 \times 10^{6}\right.$ conidia/ml $)$.

Table 6. Average lesion diameter on 'McIntosh' apples inoculated with increasing concentrations of Penicillium expansum conidia and fumigated with acetic acid at $5 \mathrm{C}$.

\begin{tabular}{llcr}
\hline \hline & \multicolumn{3}{c}{ Lesion diam $(\mathrm{mm})$} \\
\cline { 2 - 4 } Conidia/ml & \multicolumn{3}{c}{ Acetic acid (mg.liter $\left.{ }^{-1}\right)$} \\
\cline { 2 - 4 } $10^{2}$ & $16.0 \pm 13.8^{\mathrm{z}}$ & 2.0 & $0.0 \pm 0.0$ \\
$10^{3}$ & $36.3 \pm 1.5$ & $1.7 \pm 2.9$ & $0.0 \pm 0.0$ \\
$10^{4}$ & $34.0 \pm 1.7$ & $12.1 \pm 10.5$ & $0.0 \pm 0.0$ \\
$10^{5}$ & $39.7 \pm 1.5$ & $24.9 \pm 4.4$ & $0.0 \pm 0.0$ \\
\hline
\end{tabular}

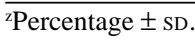

Table 7. Average lesion diameter on apples fumigated with acetic acid at 1 and 5C.

\begin{tabular}{|c|c|c|c|c|c|}
\hline \multirow{4}{*}{$\begin{array}{l}\text { Acetic } \\
\text { acid } \\
\left(\mathrm{mg} \cdot \text { liter }^{-1}\right)\end{array}$} & \multirow{4}{*}{$\begin{array}{l}\text { Apple } \\
\text { cultivar }\end{array}$} & \multicolumn{4}{|c|}{ Lesion diam (mm) } \\
\hline & & \multirow{2}{*}{\multicolumn{2}{|c|}{$\begin{array}{c}\text { Botrytis cinerea }^{2} \\
\text { Temp }\left({ }^{\circ} \mathrm{C}\right)\end{array}$}} & \multirow{2}{*}{\multicolumn{2}{|c|}{$\begin{array}{c}\text { Penicillium expansum }^{\mathrm{y}} \\
\text { Temp }\left({ }^{\circ} \mathrm{C}\right)\end{array}$}} \\
\hline & & & & & \\
\hline & & 1 & 5 & 1 & 5 \\
\hline \multirow[t]{2}{*}{$\overline{0}$} & Red Delicious & $13.7 \pm 6.7^{x}$ & $28.2 \pm 4.6$ & $24.2 \pm 8.8$ & $34.3 \pm 3.0$ \\
\hline & Spartan & $40.5 \pm 16.4$ & $2.4 \pm 4.2$ & $33.2 \pm 3.2$ & $30.7 \pm 2.0$ \\
\hline \multirow[t]{2}{*}{2.0} & Red Delicious & $0.0 \pm 0.0$ & $0.0 \pm 0.0$ & $1.4 \pm 2.5$ & $29.2 \pm 5.2$ \\
\hline & Spartan & $0.0 \pm 0.0$ & $0.0 \pm 0.0$ & $32.0 \pm 1.2$ & $8.0 \pm 3.8$ \\
\hline \multirow[t]{2}{*}{2.7} & Red Delicious & $0.0 \pm 0.0$ & $0.0 \pm 0.0$ & $0.0 \pm 0.0$ & $6.5 \pm 6.4$ \\
\hline & Spartan & $0.0 \pm 0.0$ & $0.0 \pm 0.0$ & $0.0 \pm 0.0$ & $3.0 \pm 5.2$ \\
\hline \multirow[t]{2}{*}{4.0} & Red Delicious & $0.0 \pm 0.0$ & $0.0 \pm 0.0$ & $0.0 \pm 0.0$ & $0.0 \pm 0.0$ \\
\hline & Spartan & $0.0 \pm 0.0$ & $0.0 \pm 0.0$ & $0.0 \pm 0.0$ & $0.0 \pm 0.0$ \\
\hline
\end{tabular}

${ }^{\mathrm{z} A p p l e s}$ were inoculated with $20-\mu \mathrm{l}$ drops containing $4.4 \times 10^{4} \mathrm{~B}$. cinerea conidia $/ \mathrm{ml}$.

${ }^{y}$ Apples were inoculated with $20-\mu$ l drops containing $7.8 \times 10^{5} P$. expansum conidia/ml.

xPercentage $\pm \mathrm{SD}$.

Table 8. Average lesion diameter on 'Spartan' apples fumigated with acetic acid at $17 \%$ and $98 \%$ relative humidity $(\mathrm{RH})$.

\begin{tabular}{|c|c|c|c|c|c|}
\hline \multirow{3}{*}{$\begin{array}{l}\text { Acetic } \\
\text { acid } \\
\left(\mathrm{mg} \cdot \text { liter }^{-1}\right)\end{array}$} & \multirow{3}{*}{$\begin{array}{l}\mathrm{RH} \\
(\%)\end{array}$} & \multicolumn{4}{|c|}{ Lesion diam (mm) } \\
\hline & & \multicolumn{2}{|c|}{ Botrytis cinerea $^{2}$} & \multicolumn{2}{|c|}{ Penicillium expansum ${ }^{\mathrm{y}}$} \\
\hline & & $5 \mathrm{C}$ & $20 \mathrm{C}$ & $5 \mathrm{C}$ & $20 \mathrm{C}$ \\
\hline \multirow[t]{2}{*}{0} & 17 & $28.7 \pm 5.8^{x}$ & $21.7 \pm 10.8$ & $30.9 \pm 1.8$ & $33.0 \pm 1.2$ \\
\hline & 98 & $39.2 \pm 9.4$ & $27.0 \pm 1.0$ & $34.6 \pm 1.2$ & $32.4 \pm 0.8$ \\
\hline \multirow[t]{2}{*}{2.0} & 17 & $46.0 \pm 1.7$ & $6.1 \pm 4.9$ & $31.6 \pm 4.1$ & $33.9 \pm 4.2$ \\
\hline & 98 & $0.0 \pm 0.0$ & $0.0 \pm 0.0$ & $26.4 \pm 4.0$ & $20.4 \pm 9.7$ \\
\hline \multirow[t]{2}{*}{2.7} & 17 & $25.7 \pm 2.2$ & $2.0 \pm 3.5$ & $30.1 \pm 1.6$ & $29.5 \pm 2.1$ \\
\hline & 98 & $0.0 \pm 0.0$ & $0.0 \pm 0.0$ & $25.9 \pm 1.0$ & $1.2 \pm 2.1$ \\
\hline
\end{tabular}

${ }^{\mathrm{z}}$ Apples were inoculated with $20-\mu \mathrm{l}$ drops containing $1.2 \times 10^{4} \mathrm{~B}$. cinerea conidia/ml at 5 and $20 \mathrm{C}$.

${ }^{y}$ Apples were inoculated with $20-\mu \mathrm{l}$ drops containing $1.0 \times 10^{6}$ and $4.0 \times 10^{5} \mathrm{P}$. expansum conidia/ml at 5 and 20C, respectively.

xPercentage $\pm \mathrm{SD}$. 
expansum conidia also showed that AA fumigation was more effective at $98 \%$ RH than at $17 \% \mathrm{RH}$. Lesions caused by $P$. expansum conidia fumigated at $20 \mathrm{C}$ with $2.7 \mathrm{mg} \mathrm{AA} / \mathrm{liter}$ at $17 \% \mathrm{RH}$ were $29.5 \mathrm{~mm}$ in diameter compared to $1.2 \mathrm{~mm}$ in diameter for fruit fumigated at $98 \% \mathrm{RH}$.

Fumigation of fruit immersed in a conidial suspension. Fumigation with AA at 2.7 $\mathrm{mg} \cdot \mathrm{liter}^{-1}$ following dipping the fruit into a water suspension of $P$. expansum conidia (1.4 $\times 10^{5} / \mathrm{ml}$ ) reduced decay on 'Spartan' apples from an average of 6.1 to 0.7 lesions per fruit (Fig. 2). Increasing the concentration of AA to
$>2.7 \mathrm{mg} \cdot \mathrm{liter}^{-1}$ had no significant effect on reducing the number of lesions.

$A A$ concentration during fumigation. Although the applied dosage of AA was 2.7 $\mathrm{mg} \cdot \mathrm{liter}^{-1}$, the actual concentrations within the chamber were lower (Fig. 3) due to sorption by chamber and fruit surfaces. The maximum concentrations in empty chambers were 1.8 and $1.4 \mathrm{mg} \cdot \mathrm{liter}^{-1}$ at 20 and $5 \mathrm{C}$, respectively. During the fumigation, the concentration gradually fell to $\approx 1.2 \mathrm{mg} \cdot$ liter $^{-1}$. With six apples in the chamber, concentrations were even lower. The apples were exposed to maxima of $1.6 \mathrm{mg} \cdot \mathrm{liter}^{-1}$ at $20 \mathrm{C}$ and $1.2 \mathrm{mg} \cdot \mathrm{liter}^{-1}$ at $5 \mathrm{C}$.

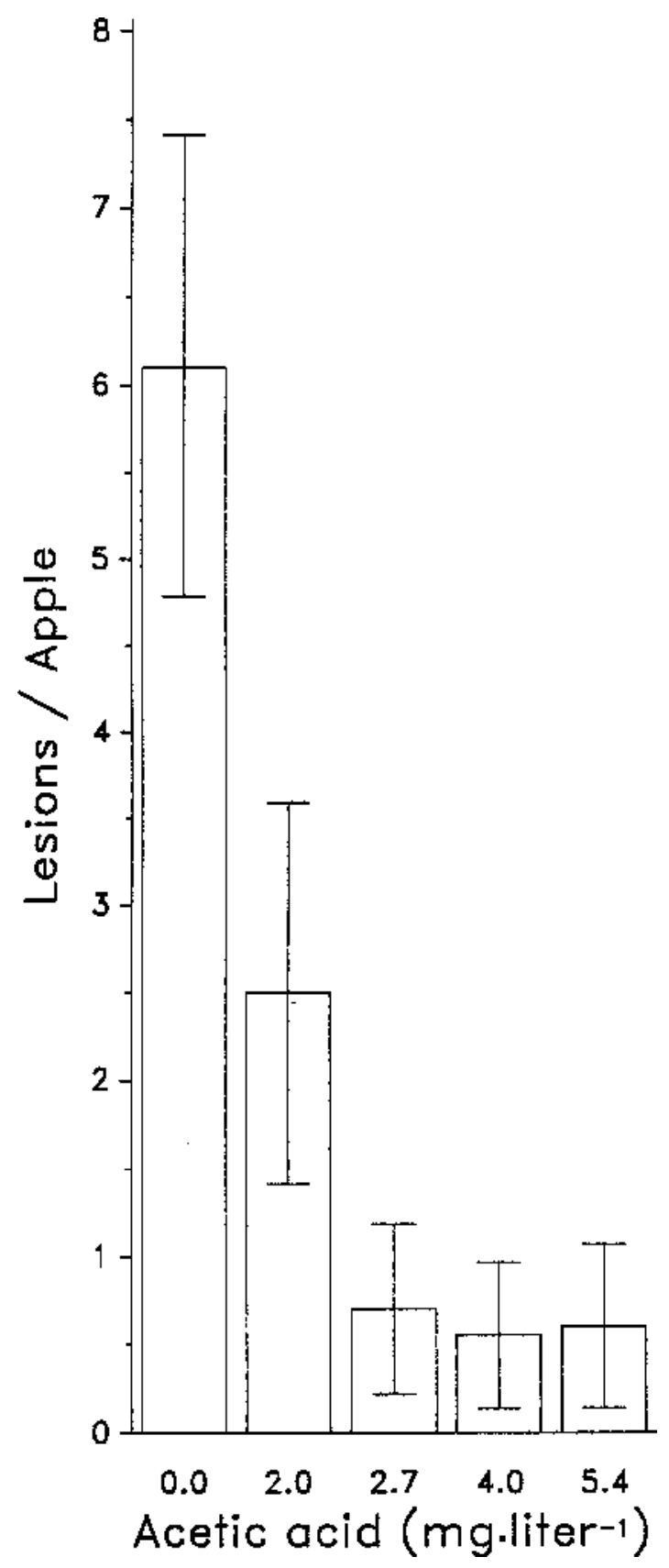

Fig. 2. Effect of acetic acid (AA) fumigation on the number of lesions per apple. 'Spartan' apples were dipped in a water suspension of Penicillium expansum conidia $\left(1.5 \times 10^{5}\right.$ conidia/ml $)$ and fumigated with AA at 2.0, 2.7, 4.0, and $5.4 \mathrm{mg} \mathrm{liter}^{-1}$ in four chambers containing 20 apples each. After fumigation, the apples were injured at 12 locations on each fruit with a glass rod ( $3 \mathrm{~mm}$ in diameter) and then incubated at $22 \pm 2 \mathrm{C}$ for 7 days.

\section{Discussion}

Using liquid AA solutions to control decay and preserve fruit and vegetables has been well documented (Banwart, 1981). AA was screened as a fumigant against conidia of Monilinia fructicola (Wint.) Honey and reduced the germination to zero (Roberts and Dunegan, 1932); however, research on its use was not pursued any further because AA at the concentration used in this test blackened the fruit in a few minutes. To our knowledge, using concentrated AA in vapor form for controlling decay-causing organisms on apples and fruit other than peaches has not been explored.

Research has been done with other volatile compounds. Shaw (1969) discovered that decay in strawberries (Fragaria Xananassa Duch.) inoculated with spores of Botrytis and Rhizopus was reduced when stored in a high$\mathrm{CO}_{2}$ atmosphere due to the production of high levels of acetaldehyde and ethyl acetate by the fruit in response to these conditions. Acetaldehyde vapors were toxic to bacterial pathogens, such as Erwinia carotovora (Jones) Holland and Pseudomonas fluorescens Migula and fungal pathogens (Aharoni and Stadelbacher, 1973). Decay of raspberries (Rubus idaeus L.) and strawberries inoculated with Botrytis cinerea and apples inoculated with Penicillium expansum were controlled by fumigation with acetaldehyde vapor (Prasad and Stadelbacher, 1973; Stadelbacher and Aharoni, 1971; Stadelbacher and Prasad, 1974). Treatment of 'Sultanina' grapes with 5000 ppm acetaldehyde vapors for $24 \mathrm{~h}$ reduced decay by 92\% compared to control fruit (Avissar et al., 1989). Vapor of (2-hydroxybenzoic acid methy ester) ethyl benzoate (benzaldehyde) totally inhibited spore germination of $B$. cinerea at 25 $\mu \mathrm{l} \cdot$ liter $^{-1}$ and germination of Monilinia fructicola at $125 \mu 1 \cdot \mathrm{ml}^{-1}$ (Wilson et al., 1987). Methyl salicylate and ethyl benzoate also were effective against spore germination of $M$. fructicola and B. cinerea. However, none of these vapor treatments have been adopted for commercial use, probably because of the high cost of the vapor, government regulations on use of such products, and other hazards, such as flammability.

AA vapor at relatively low concentrations has many qualities that make it an excellent biocide. First, it kills fungal spores. This result was shown when conidia of $B$. cinerea and $P$. expansum did not germinate on buffered PDA medium and fruit that had been inoculated and injured did not become infected after AA fumigation. Second, it does not injure the fruit surface. Fumigations with AA vapor concentrations $\leq 5.4 \mathrm{mg} \cdot$ liter $^{-1}$ did not cause damage to the apple surface. Third, it is effective at low temperatures, which means that fruit in $1 \mathrm{C}$ cold storage could be effectively treated with AA vapor. In addition to these qualities, AA is not flammable at concentrations that are required to kill spores.

Fungal spores are most susceptible to AA vapor at high RH (under low VPD). Our tests showed that fumigation was more effective at $98 \% \mathrm{RH}$ than at $17 \% \mathrm{RH}$. In some of our 


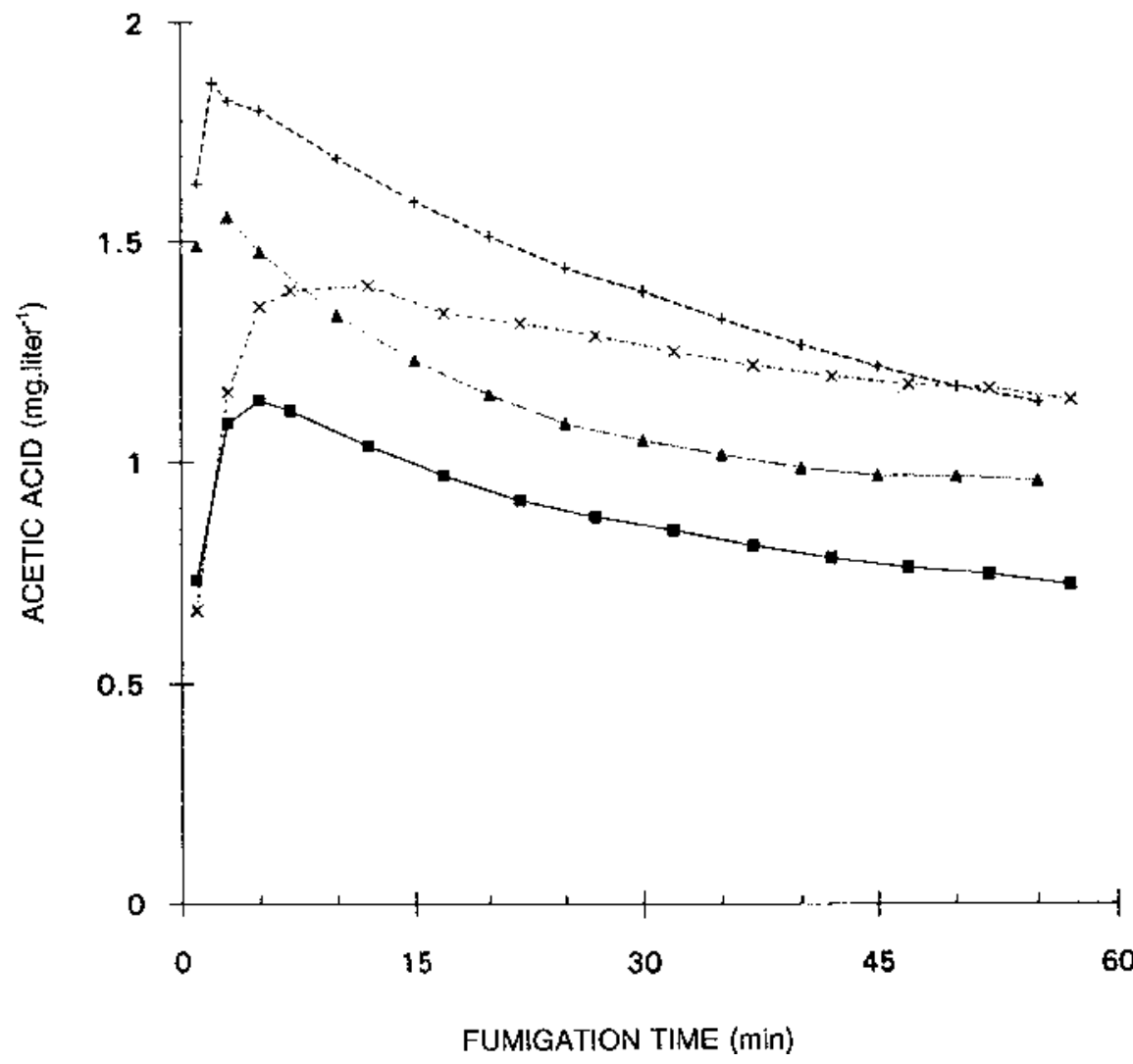

Fig. 3. Concentration of acetic acid in air during fumigation. The fumigation curves are averages of at least two runs with applied dosage of $2.7 \mathrm{mg} \cdot \mathrm{liter}^{-1}$, chamber empty at (+) 20 or (A) 5C or with six 'Red Delicious' apples at $(\times) 20$ or ( $\mathbf{\square}) 5 \mathrm{C}$.

earlier tests, the results were erratic; for example, when we fumigated conidia on dialysis tubing, they were not always killed, although we used concentrations that normally killed the conidia on PDA. These inconsistent results disappeared when the fumigation was done in air with $95 \%$ to $100 \%$ RH. Couey and Uota (1961) reported a similar increase in susceptibility of Botrytis cinerea spores to $\mathrm{SO}_{2}$ fumigation at high RH.

In our study, AA vapor was tested on several apple cultivars, pears, grapes, kiwifruit, and tomato fruit against $P$. expansum, $B$. cinerea, or both. We also tested it on other tree fruit for control of $M$. fructicola and on strawberries against $B$. cinerea with promising effectiveness (Sholberg and Gaunce, unpublished data). AA fumigation offers promise as a method for surface-sterilizing a wide range of fruit and possibly vegetable crops. For some crops, effective surface sterilization may lead to extended storage or shelf life. AA vapor is a potential replacement for the sulfur dioxide currently used to control decay in stored table

\section{Literature Cited}

Aharoni, Y. and G.J. Stadelbacher. 1973. The toxicity of acetaldehyde vapors to postharvest pathogens of fruits and vegetables. Phytopathology 63:544-545

Avissar, I., R. Marinansky, and E. Pesis. 1989. Postharvest decay control of grape by acetaldehyde vapors. Acta Hort. 258:655-660.

Banwart, G.J. 1981. Basic food microbiology. AVI, Westport, Conn.

Busta, F.F. and P.M. Foegeding. 1983. Chemical food preservatives, p. 656-688. In: S.S. Block (ed.). Disinfection, sterilization, and preservation. Lea \& Febiger, Philadelphia.

Couey, H.M. and M. Uota. 1961. Effect of concentration, exposure time, temperature, and relative humidity on the toxicity of sulfur dioxide to the spores of Botrytis cineria. Phytopathology $51: 815-819$.

Janisiewicz, W. 1988. Biological control of diseases of fruits, p. 153-165. In: K.G. Mukerji and K.L. Garg (eds.). Biocontrol of plant diseases. vol. 2. CRC Press, Boca Raton, Fla.

Janisiewicz, W. 1991. Biological control of postharvest fruit diseases, p. 301-326. In: D.K. Arora, B. Rai, K.G. Mukerji, and G.R. Knudsen (eds.). Handbook of applied mycology, vol. 1. Soils and plants. Marcel Dekker, New York.

Jeffries, P. and M.J. Jeger. 1990. The biological control of postharvest diseases of fruit. Postharvest News and Info. 5:365-368.

Kelman, A. 1989. Introduction: The importance of research on the control of postharvest diseases of perishable food crops. Phytopathology 79:1374.

Prasad, K. and G.J. Stadelbacher. 1973. Control of postharvest decay of fresh raspberries by acetaldehyde vapor. Plant Dis. Rptr. 57:795-797.

Roberts, J.W. and J.C. Dunegan. 1932. Peach brown rot. Tech. Bul. 328. U.S. Dept. of Agriculture, Washington, D.C.

Shaw, G.W. 1969. The effect of controlled atmosphere storage on the quality and shelf-life of fresh strawberries with special reference to Botrytis cinerea and Rhizopus nigricans. $\mathrm{PhD}$ Diss., Univ. of Maryland, College Park.

Smilanick, J.L., P.L. Hartsell, D. Henson, D.C. Fouse, M. Assemi, and C.M. Harris. 1990. Inhibitory activity of sulfur dioxide on the germination of spores of Botrytis cinerea. Phytopathology 80:217-220.

Stadelbacher, G.J. and Y. Aharoni. 1971. Acetaldehyde vapor treatment to control postharvest decay in strawberries. HortScience 6:280. (Abstr.)

Stadelbacher, G.J. and K. Prasad. 1974. Postharvest decay control of apple by acetaldehyde vapor. J. Amer. Soc. Hort. Sci. 99:364-368.

Wilson, C.L., J.D Franklin, and B.E. Otto. 1987. Fruit volatiles inhibitory to Monilinia fructicola and Botrytis cinerea. Plant Dis. 71:316-319.

Wilson, C.L. and M. Wisniewski. 1989. Biological control of postharvest diseases. Annu. Rev. Phytopathol. 27:425-441.

Wilson, C.L., M.E. Wisniewski, C.L. Biles, R. McLaughlin, E. Chalutz, and S. Droby. 1991. Biological control of post-harvest diseases of fruits and vegetables: Alternatives to synthetic fungicides. Crop Protection 10:172-177. 